\title{
PENINGKATAN HASIL BELAJAR SISWA MENGGUNAKAN METODE PEMBELAJARAN THINK-TALK-WRITE (TTW) PADA MATA PELAJARAN PENDIDIKAN KEWARGANEGARAAN
}

\author{
Elwaldus Odo Ventura ${ }^{1}$, Rohani $^{2}$ \\ 1,2 Program Studi PPKN Fakultas Ilmu Pendidikan dan Pengetahuan Sosial IKIP PGRI Pontianak \\ Jl. Ampera Nomor 88 Pontianak-78116, Telepon (0561) 748219 Fax. (0561) 6589855 \\ Email: ${ }^{1}$ rohani@ikippgriptk.ac.id
}

\begin{abstract}
Abstrak
Penelitian ini bertujuan untuk meningkatkan hasil belajar siswa melalui metode pembelajaran Think-Talk-Write (TTW) pada mata pelajaran pendidikan kewarganegaraan. Penelitian ini menggunakan pendekatan kualitatif dengan metode penelitian tindakan dan bentuk penelitiannya penelitian tindakan kelas. Hasil penelitian menunjukkan bahwa penerapan metode pembelajaran Think-Talk-Write (TTW) dapat meningkatkan hasil belajar siswa. Terdapat peningkatan hasil belajar setiap siklusnya melalui penerapan metode pembelajaran Think-Talk-Write (TTW). Hasil belajar siklus I terdapat 18 orang siswa yang tuntas dan yang belum tuntas 11 orang siswa, nilai tertinggi 85 dan nilai terendah 55 dengan nilai rata-rata mencapai 71,93 dan ketuntasan klasikal mencapai 62\%. Selanjutnya evaluasi hasil belajar siklus II terdapat 25 orang siswa yang tuntas dan yang belum tuntas 4 orang siswa , nilai tertinggi 90 dan nilai terendah 65, dengan nilai rata-rata 77,10 dan ketuntasan klasikal mencapai 86\% dengan kategori tinggi.
\end{abstract}

Kata Kunci: Hasil Belajar, Metode Think-Talk-Write.

\begin{abstract}
This study aims to improve student learning outcomes through the Think-Talk-Write (TTW) learning method on citizenship education subjects. This study uses a qualitative approach with action research methods and forms of research into classroom action research. The results showed that the application of Think-Talk-Write (TTW) learning methods can improve student learning outcomes. There is an increase in learning outcomes each cycle through the application of Think-Talk-Write (TTW) learning methods. Learning outcomes in the first cycle there were 18 students who completed and who did not complete 11 students, the highest score was 85 and the lowest score was 55 with an average score of 71.93 and classical completeness reached $62 \%$. Furthermore evaluation of learning outcomes in cycle II there are 25 students who have completed and who have not completed 4 students, the highest score is 90 and the lowest score is 65, with an average score of 77.10 and classical completeness reaching $86 \%$ with a high category.
\end{abstract}

Keyword: learning Outcomes, Think-Talk-Write

\section{PENDAHULUAN}

Pada umumnya pendidikan di Indonesia bertujuan untuk meningkatkan kualitas hidup manusia secara teknis operasional dilakukan melalui suatu proses pembelajaran. UU No. 20 Tahun 2003 Bab 1 Pasal 1 menyebutkan bahwa "Pendidikan adalah usaha sadar dan terencana untuk mewujudkan suasana belajar dan proses pembelajaran agar peserta didik secara aktif mengembangkan potensi dirinya untuk memiliki kekuatan spritual keagamaan, pengendalian diri, kepribadian, kecerdasan, akhlak mulia, serta keterampilan yang diperlukan dirinya, bangsa dan negara".

Pendidikan merupakan modal dasar dari pembangunan menuju kemajuan dan perkembangan. Oleh karena itu penyelenggaraan pendidikan bagi peningkatan suatu bangsa merupakan hal yang sangat penting dan perlu mendapatkan perhatian yang sangat khusus. Pendidikan pada dasarnya, suatu proses untuk membantu manusia dalam mengembangkan dirinya, sehingga mampu menghadapi 
segala perubahan dan permasalahan dengan sikap terbuka serta dengan pendekatan yang kreatif tanpa harus kehilangan identitas dirinya.

Dalam belajar siswa diharapkan mampu mencapai hasil belajar yang memuaskan dalam diri maupun bagi masyarakat,bangsa,dan negara. Pendidikan merupakan salah satu upaya yang dilakukan pemerintah untuk membentuk seseorang agar memiliki pengetahuan, keterampilan, dan nilai serta norma yang diperlukannya didalam kehidupan bermasyarakat. Hal ini akan dapat tercapai jika proses pendidikan berjalan sebagai mestinya, sesuai dengan apa yang diharapkan. Bangsa Indonesia pada era globalisasi sekarang akan berusaha keras untuk meningkatkan mutu pendidikan, baik dijenjang sekolah dasar, sekolah menenggah pertama, sekolah menenggah atas bahkan sampai kejenjang perguruan tinggi.

Namun sayangnya praktek pembelajaran belum terlaksana secara keseluruhan, sehingga tujuan dan hasil pendidikan belum sesuai dari apa yang diharapkan. Seorang guru perlu melakukan berbagai metode ataupun model pembelajaran untuk meningkatkan hasil belajar siswa. Bahkan strategi, metode dan model yang digunakan haruslah sesuai dengan situasi dan kondisi yang ada dilingkungan tempat melakukan proses pembelajaran sehingga hasil belajar siswa meningkat dalam proses belajar.

Proses pembelajaran di suatu sekolah pada hakikatnya adalah upaya yang dilakukan oleh guru untuk membuat siswa belajar. Dengan demikian kegiatan di kelas atau di sekolah yang tidak membuat siswa belajar tidak dapat disebut sebagai proses pembelajaran. Pendidikan bagi kehidupan umat manusia merupakan salah satu kebutuhan mutlak bagi setiap individu yang harus dipenuhi. Dengan adanya pendidikan menjadikan setiap individu mengalami perubahan ke arah yang lebih baik. Perkembangan dunia pendidikan yang semakin pesat, menjadi tugas berat bagi negara khususnya bagi guru untuk mencerdaskan warga negara, melalui pemberian hak belajar agar lebih maju dalam berfikir guna mempersiapkan diri dalam persaingan global. Pendidikan di Indonesia mengingginkan masyarakatnya menjadi lebih maju dari berbagai aspek pemikiran, keterampilan dan sikap. Mengenai pemikiran dan, keterampilan, dan sikap yang baik sudah ada dipelajari dan diterapkan pada mata pelajaran Pendidikan Pancasila dan Kewarganegaraan.

Pelajaran Pendidikan Pancasila dan Kewarganegaraan adalah pelajaran yang mengajarkan berbagai pengetahuan yang dapat mengembangkan daya nalar, analisa sehingga hampir semua persoalan yang berkaitan dengan kehidupan sosial dimasyarakat dapat dimengerti. Untuk dapat mengerti Pendidikan Pancasila dan Kewarganegaraan secara luas, maka harus dimulai dengan kemampuan pemahaman konsep dasar yang ada pada pelajaran Pendidikan Pancasila dan Kewarganegaraan.

Menurut Hamid Darmadi (2010:30) Pendidikan Pancasila dan Kewarganegaraan adalah upaya membangun nation and character building. Hal itu dapat dilaksanakan apabila secara dini kesadaran 
bela negara ditanamkan kepada setiap warga negara, untuk kemudian menjadi sikap mental dan nilai Kewarganegaraan adalah usaha sadar dan terencana untuk mewujudkan warga negara yang memiliki kesadaran berbangsa dan bernegara untuk membela negara dengan prilaku cinta tanah air. Berdasarkan pendapat diatas, maka dapat disimpulkan bahwa Pendidikan Pancasila dan Kewarganegaran adalah suatu pembelajaran yang dilakukan secara sadar, dimana untuk mempersiapkan peserta didik menjadi warga negara yang memahami hak dan kewajiban, dan dapat mengembangkan pengetahuan serta melestarikan nilai-nilai leluhur bangsa dalam bentuk prilaku dikehidupan sehari-hari. Hal tersebut bertujuan untuk membuat siswa aktif dalam proses belajar, baik dilingkungan sekolah maupun diluar lingkungan sekolah agar dapat meningkatkan hasil belajar siswa tersebut.

Hasil belajar dapat tercapai apabila guru dalam menyampaikan pelajaran tidak menjadikan siswa sebagai obyek belajar, tetapi siswa dijadikan sebagai subyek, sehingga siswa bisa terlibat langsung dalam proses pembelajaran. Dalam hasil pencapaian hasil belajar yang diharapkan, guru di tuntut untuk bisa membawa suasana belajar menjadi sesuatu yang tidak membosankan atau monoton, belajar yang tidak membosankan akan memacu interaksi antara siswa dan guru, siswa dengan siswa, serta antara siswa dengan materi pelajaran (multi interaksi). Pembelajaran memiliki dampak terhadap hasil belajar siswa, dengan guru sebagai pemegang peran utama dalam pendidikan. Dalam perkembangan ilmu dan teknologi sangat berpengaruh terhadap hasil belajar maupun kegiatan yang dilakukan siswa dalam proses belajar dilingkungan sekolah yang formal maupun non-formal.

Ada banyak metode yang mampu memaksimalkan hasil belajar siswa dalam pembelajaran, diantaranya berpikir atau memikirkan, membicarakan atau berdiskusi, menuliskan ide-ide dan metode tersebut adalah Think-Talk-Write (TTW). Pada dasarnya keberhasilan proses pembelajaran dipengaruhi juga oleh lingkungan, pengajar merupakan instruktur yang memberikan perintah atau mengarahkan peserta didik untuk mengikuti proses pembelajaran dengan benar, sehingga peserta didik dapat mengikuti proses pembelajaran sangat senang. Keberhasilan belajar mengajar tidak luput di pengaruhi oleh kreatifitas dan kepandaian seorang guru dalam mengajar dan menerapkan metode ataupun model pembelajaran. Tujuan diterapkannya metode atau model pembelajaran adalah untuk membantu siswa dalam mendapatkan atau memperoleh informasi, ide, keterampilan, cara berfikir, dan mengekspresikan diri sendiri.

Hal ini sejalan dengan beberapa hasil penelitian tindakan seperti yang dilakukan Rohani dan Samsiar (2017:58), menyatakan bahwa terdapat peningkatan civic knowledge siswa melalui penerapan model pembelajaran controversial issues pada mata pelajaran pendidikan kewarganegaraan dikelas VIII Sekolah Menegah Pertama Mujahidin Pontianak. Bisa dilihat dari perolehan tes hasil belajar siswa dimulai dari pra siklus mendapat ketuntasan klasikal 37,8\% dengan nilai rata-rata 69, ditunjukan dengan siklus I mengalami peningkatan dengan ketuntasan klasikal 56,75\% dengan nilai rata-rata 
71,35 dan siklus II mengalami peningkatan dengan ketuntasan klasikal 77,14\% dengan nilai rata-rata 80. Selanjutnya penelitian lain Rohani menyatakan bahwa Terdapat peningkatan kemampuan kogntitif mahasiswa dengan menggunakan model course review horay pada mata kuliah pengantar pendidikan semester I Program Studi PPKn. Kemampuan kognitif mahasiswa pra siklus yang berjumlah 33 orang memperoleh nilai tuntas sebanyak 11 orang mahasiswa yaitu 33\% dengan persentase ketuntasan secara klasikal yaitu $25,82 \%$. Setelah dilakukan siklus I mahasiswa yang memperoleh nilai tuntas sebanyak 16 orang mahasiswa yaitu 48\% dengan persentase ketuntasan klasikal sebesar 40,91\% dari 33 orang mahasiswa yang mengikuti tes. Selanjutnya setelah dilakukan siklus II mahasiswa yang memperoleh nilai tuntas sebanyak 29 orang mahasiswa yaitu $88 \%$ dengan persentase ketuntasan klasikal sebesar 70,85\% dari 33 orang mahasiswa yang mengikuti tes. Dari beberapa penelitian di atas dapat disimpulkan bahwa penerapan model pembelajaran dapat meningkatkan hasil belajar.

Think-Talk-Write (TTW) adalah strategi yang memfasilitasi latihan berbahasa secara lisan dan menuliskan bahasa tersebut dengan lancar. Strategi Think-Talk-Write (TTW) memperkenankan siswa untuk mempengaruhi dan memanipulasi ide-ide sebelum menuangkannya dalam bentuk tulisan. Ia juga membantu siswa dalam mengumpulkan dan mengembangkan ide-ide melalui percakapan terstruktur. Dalam penerapan pembelajaran menggunakan metode pembelajaran Think-Talk-Write (TTW) memerlukan bimbingan yang maksimal dari pengajar, hal tersebut untuk bisa dapat memfasilitasi pembelajaran peserta didik dengan kreatifitas.

Alasan peneliti menerapkan metode pembelajaran Think-Talk-Write (TTW) adalah untuk melatih siswa dalam proses belajar mengajar agar siswa dapat belajar dengan baik sehingga berpengaruh terhadap nilai akhir siswa menjadi meningkat. Kaitan metode pembelajaran Think-TalkWrite (TTW) terhadap mata pelajaran Pendidikan Kewarganegaraan (PKn) adalah metode pembelajaran Think-Talk-Write (TTW) ini bisa melatih siswa dalam berbahasa secara lisan maupun tulisan agar siswa menjadi lebih kritis terhadap pelajaran Pendidikan Kewarganegaraan (PKn).

Pengajar memberikan kesempatan kepada peserta didik untuk menggembangkan cara-cara belajarnya yang disimulus oleh pengajar. Ada berbagai faktor yang diyakini memiliki pengaruh langsung terhadap keberhasilan perserta didik dalam proses belajar disekolah. Faktor tersebut meliputi profesional guru, ketersediaan sarana dan prasarana belajar, kurikulum, bahan ajar, maupun faktorfaktor yang berkaitan secara langsung dengan siswa selaku peserta didik dalam menerima dan menjalani aktifitas belajar.

Pada proses pembelajaran tidak hanya terbatas oleh pendapat guru saja, tetapi mencakup semua cara belajar yang mempunyai pengaruh langsung pada pembelajaran yang meliputi kejadian-kejadian, yang diturunkan dari berbagai media pembelajaran untuk mencapai tujuan yang direncanakan. Metode dan model pembelajaran yang monoton dan tidak menarik serta hanya berorientasi pada guru tanpa 
kreatifitas guru dalam mengajar menyebabkan peserta didik tidak berminat dalam mengikuti pembelajaran dan tidak termotivasi dalam belajar dan melakukan hal-hal yang dapat menghambat proses pembelajaran dan bisa menimbulkan situasi yang tidak kondusif.

Dari hasil pra observasi di Sekolah Menengah Atas Negeri 1 Banyuke Hulu Kabupaten Landak pada Selasa 26 Februari 2018 pukul 08:00 pagi bahwa proses pembelajaran pendidikan kewarganegaraan, diketahui dalam peyampaian materi pendidikan kewarganegaraan, ditemukan hasil belajar siswa yang belum maksimal, hal ini tampak pada nilai akhir siswa. Rendahnya pencapaian nilai akhir siswa ini, menjadi indikasi bahwa pembelajaran yang dilakukan belum efektif.

Pada kenyataan disekolah hasil belajar yang diperoleh siswa pada pembelajaran pendidikan kewarganegaraan masih rendah atau kurang optimal. Hal ini disebabkan karena guru cenderung menggunakan metode ceramah yang monoton dan berakibat pada siswa yang mudah bosan dalam pembelajaran, ngantuk dan sebagainya. Dari hasil pengamatan pra-observasi bahwa hasil nilai mata pelajaran pendidikan kewarganegaraan Sekolah Menenggah Atas Negeri 1 Banyuke Hulu, bahwa untuk nilai rata-rata pada mata pelajaran pendidikan kewarganegaraan masih rendah yaitu sebesar 63,00 dan bisa dikatakan bahwa nilai klasikal siswa belum tercapai dikarenakan masih ada sebagian besar siswa yang belum tuntas pada mata pelajaran Pendidikan dan Kewarganegaraan (PKn).

Untuk itu guru harus mempunyai dan memiliki pengetahuan yang luas mengenai model dan metode pembelajaran, jenis-jenis belajar, dan suasana belajar yang kondusif, baik eksternal maupun internal. Dalam metode pembelajaran Think-Talk-Write (TTW) ini guru dituntut untuk dapat meningkatkan kreatifitas dalam pembelajaran, dalam arti guru aktif dan sebaliknya peserta didik juga harus aktif. Suatu pembelajaran yang baik adalah apabila terdapat keterlibatan antara guru dan peserta didik seimbang dalam proses pembelajaran. Supaya antara pendidik dan peserta didik dapat saling bertukar pemikiran, tidak hanya pendidik yang mengutarakan pelajaran melainkan peserta didik juga harus lebih aktif dalam belajar dan menimbulkan pembelajaran yang berkesinambunggan. Hal ini dimaksudkan agar hasil belajar siswa dapat meningkat.

Berdasarkan apa yang telah peneliti paparkan di atas, peneliti tertarik mengkaji dalam meningkatkan hasil belajar siswa. Peneliti akan menerapkan metode Think-Talk-Write (TTW) dimana dengan penerapan metode ini diharapakan dapat meningkatkan hasil belajar siswa dalam pembelajaran pendidikan kewarganegaraan sehingga siswa tidak mudah bosan, ngantuk dan sebagainya yang membuat hasil belajar siswa menurun menjadi naik. Metode tersebut akan peneliti gunakan dalam sebuah peneilitian tindakan kelas yang berjudul "Peningkatan hasil belajar siswa menggunakan metode pembelajaran Think-Talk-Write (TTW) pada mata pelajaran Pendidikan Kewarganegaraan kelas X Sekolah Menegah Atas Negeri 1 Banyuke hulu kabupaten Landak”. 


\section{METODE}

Setiap penelitian memerlukan metode penelitian. Menurut Hamid Darmadi (2014:1) menyatakan "metode penelitian adalah pembahasan mengenai konsep teoritik tentang berbagai metode, kelebihan dan kelemahan yang ada dalam karya ilmiah kemudian dilanjutkan dengan pemilihan metode yang digunakan”. Berdasarkan konsep pemikiran diatas metode peneilitian ini dapat diartikan sebagai cara yang dilakukan oleh peneliti untuk memecahkan masalah penelitian.

Menurut Zuldafrial (2012:186), "penelitian tindakan dilakukan oleh peserta yang terlibat dalam situasi yang diteliti seperti guru, siswa, atau kepala sekolah". Sedangkan menurut Gregory S.C.H (2013) menegaskan bahwa "action research is aprocess of systematic inquiry that seeks to improve social issues affecting the lives of everyday people". Hal ini dapat dipahami bahwa penelitian tindakan adalah suatu proses penyelidikan sistematis yang bertujuan untuk meningkatkan isu-isu sosial mempengaruhi kehidupan manusia sehari-hari.

Sejalan dengan pendapat di atas Burns, A. (2010: 5) mengemukakan bahwa "Action research is research carried out in the classroom by the teacher of the course, mainly with the purpose of solving a problem or improving the teaching/learning process". Hal ini menegaskan bahwa penelitian tindakan adalah penelitian yang dilakukan dikelas oleh guru kursus, terutama dengan tujuan memecahkan masalah atau meningkatkan proses pengajaran atau pembelajaran. Metode yang dipergunakan dalam penelitian ini adalah metode penelitian tindakan karena sesuai dengan tujuan penelitian ini yaitu peningkatan hasil belajar siswa menggunakan metode pembelajaran Think-TalkWrite (TTW) pada mata pelajaran Pendidikan Kewarganegaraan di kelas X Sekolah Menegah Atas Negeri 1 Banyuke Hulu Kabupaten Landak. Alasan mengunakan penelitian tindakan agar guru menemukan solusi dari masalah yang timbul dikelasnya, dan membuat guru menjadi peka dan tanggap terhadap dinamika pembelajaran dikelasnya karena guru menjadi reflektif dan kritis terhadap apa yang guru dan muridnya lakukan.

Penelitian ini dilakukan dengan mengunakan penelitian tindakan kelas (PTK) dengan tahapannya sebagai berikut :

a. Tahap Perencanaan Tindakan

Pada tahap awal penelitian ini tim peneliti melihat kemampuan siswa menguasai materi dalam penyelesaian soal melalui pemberian refleksi awal yaitu dengan memberikan tes tertulis. Siklus ini diperlukan untuk dijadikan kriteria pertama untuk mengukur manfaat penerapan tindakan yang dilakukan oleh peneliti bersama teman sejawat dalam proses pembelajaran. Tahap perencanaan pembelajaran meliputi :

1. Menyiapkan materi

2. Membuat rencana pelaksanaan pembelajaran (RPP) 


\section{Membuat silabus}

4. Menyiapkan media pembelajaran

5. Membuat instrumen penelitian

6. Menyiapkan kisi-kisi soal

b. Tahap Pelaksanaan Tindakan

Dalam proses penelitian siklus 1, guru sebagai peneliti berlatih melakukan kegiatan yaitu mengimplementasikan kegiatan pembelajaran yang langkah-langkahnya sesuai dengan kegiatan belajar mengajar dengan menggunakan metode pembelajaran Think-Talk-Write (TTW). Metode pembelajaran Think-Talk-Write menurut (Martinis Yamin \& Bansu 2008:90) mempunyai langkah - langkah sebagai berikut :

1. Guru membagi teks bacaan berupa lembaran kerja siswa yang memuat petunjuk serta prosedur pelaksanaan.

2. Siswa membaca teks dan membuat rangkuman atau catatan dari hasil bacaan individual (think), untuk dibawa ke forum diskusi.

3. Siswa berkolaborasi dan berinteraksi dengan teman satu grup untuk membahas isi catatan (talk). Dalam kegiatan ini mereka menggunakan bahasa dari kata-kata mereka sendiri untuk menyampaikan ide-ide materi pelajaran dalam diskusi. Pemahaman dibangun melalui interaksi dalam diskusi, karena itu diskusi diharapkan dapat menghasilkan solusi atas soal yang diberikan.

4. Siswa mengkontruksi sendiri pengetahuan yang memuat pemahaman dan komunikasi dalam bentuk tulisan (write).

5. Kegiatan akhir adalah membuat refleksi dan kesimpulan atas materi yang dipelajari. Sebelum itu, dipilih salah satu atau beberapa orang siswa sebagai perwakilan kelompok untuk menyajikan jawaban, sedangkan kelompok lain diminta memberikan tanggapan.

c. Tahap Pengamatan (Observasi)

Observasi akan dilakukan pada saat pelaksanaan tindakan yang dilakukan oleh peneliti dengan menggunakan instrumen observasi yang telah dipersiapkan. Observasi ini dimaksudkan untuk mendeskripsikan sejauh mana langkah-langkah pembelajaran dengan menggunakan metode pembelajaran Think-Talk-Write (TTW)

d. Tahap Refleksi

Kegiatan ini sangat tepat dilakukan ketika pelaksana sudah selesai melakukan tindakan, kemudian peneliti bersama guru mata pelajaran pendidikan kewarganegaraan melakukan evaluasi dengan melihat kelebihan dan kekurangan pelaksanaan tindakan selama proses pembelajaran pada siklus 1 . Peneliti bersama guru pelaksana mendiskusikan kembali rencana 
tindakan yang akan dilakukan pada siklus II. Pada siklus II, kekurangan-kekurangan pada siklus 1 akan diperbaiki.

\section{HASIL DAN PEMBAHASAN}

Berdasarkan permasalahan yang dirumuskan pada bab satu serta deskripsi hasil penelitian maka dapat disimpulkan bahwa penerapan metode pembelajaran Think-Talk-Write (TTW) dapat meningkatkan hasil belajar siswa. Selanjutnya hasil penelitian ini dikontruksikan dengan penelitian yang relevan. Berikut ini akan diuraikan pembahasan dalam penelitian tindakan kelas dengan judul " Peningkatan hasil belajar siswa mengunakan metode pembelajaran Think-Talk-Write (TTW) pada mata pelajaran pendidikan kewarganegaraan kelas X Sekolah Menengah Atas Negeri 1 Banyuke Hulu Kabupaten Landak :

Perencanaan penggunaan metode Think-Talk-Write (TTW) untuk meningkatkan hasil belajar siswa pada mata pelajaran pendidikan kewarganegaraan kelas X SMA Negeri 1 Banyuke Hulu

\section{Kabupaten Landak.}

Berdasarkan hasil observasi diperoleh data bahwa perencanaan pengunaan metode pembelajaran Think-Talk-Write (TTW) sudah berjalan dengan baik dan terdapat peningkatan dalam setiap siklusnya. Adapun perencanaan yang guru dan peneliti lakukan yaitu menyusun perangkat dan instrumen pembelajaran seperti menyiapkan materi pembelajaran, membuat dan rencana pelaskanaan pembelajaran (RPP), membuat silabus ,menyiapkan media pembelajaran, membuat instrumen penelitian dan menyiapkan kisi-kisi soal.

Hal ini sejalan dengan pendapat Arikunto, dkk. (2014:43) mengemukakan bahwa hal yang dimaksud dengan perencanaan tindakan (PTK) adalah kegiatan menyusun rencana pelaksanaan pembelajaran (RPP), yaitu kegiatan yang membuat rencana akan dilaksanakan dalam pelaksanaan tindakan. Selanjutnya Arikunto (2014:17) mengatakan bahwa "dalam tahap penyusunan rencana, peneliti menemukan titik-titik atau fokus peristiwa yang mendapatkan perhatian khusus untuk diamati, kemudian membuat sebuah instrumen pengamatan untuk membantu peneliti merekam fakta yang terjadi selama tindakan berlangsung. Jika yang digunakan dalam penelitian ini bentuk terpisah, yaitu penelitian dan pelaksanaan guru adalah berbeda, dalam tahap penyusunan rencana harus ada kesepakatan antara keduanya". Berdasarkan penjelasan yang telah dipaparkan diatas, maka dapat disimpulkan bahwa perencanaan pembelajaran merupakan proses penyusunan dari materi pembelajaran, pengunaan media pembelajaran, pengunaan metode pembelajaran, dan pengunaan alokasi waktu yang akan dilaksanakan pada proses pembelajaran berlangsung untuk mencapai tujuan yang telah ditentukan. 
Pelaksanaan metode pembelajaran Think-Talk-Write (TTW) untuk meningkatkan hasil belajar siswa pada mata pelajaran Pendidikan Kewarganegaraan pada siswa kelas X Sekolah Menengah Atas Negeri 1 Banyuke Hulu Kabupaten Landak.

Berdasarkan hasil observasi diperoleh data bahwa ada 5 (lima) langkah yang dilakukan oleh guru dalam pengunaan metode pembelajaran Think-Talk-Write (TTW) yaitu: langkah pertama adalah guru membagi teks bacaan berupa lembaran kerja siswa yang memuat petunjuk serta prosedur pelaksanaan. Pada langkah ini guru turut menjelaskan prosedur untuk kesiapan dalam pembelajaran hal ini bertujuan agar siswa paham dengan apa yang akan guru lakukan. Langkah kedua yaitu siswa membaca teks dan membuat rangkuman atau catatan dari hasil bacaan individual atau (think), untuk dibawa keforum diskusi. Pada langkah ini siswa diberikan tugas oleh guru dan dituntut untuk berfikir dalam menuangkan ide-ide lisan maupun tulisan secara individu. Langkah ketiga yaitu siswa berkolaborasi atau berinteraksi dengan teman satu grup untuk membahas isi catatan (talk). Pada langkah ketiga ini siswa diberikan kesempatan oleh guru untuk berdiskusi dengan teman satu grup atau kelompok. Langkah keempat dilanjutkan dengan siswa mengkontruksi sendiri pengetahuan yang memuat pemahaman dan komunikasi dalam bentuk tulisan (write). Pada langkah ini siswa harus bisa menuangkan gagasan atau ide-ide yang telah mereka dapatkan selama proses belajar berlangsung dengan dituangkan dibentuk tulisan. Dan langkah terakhir yaitu guru dan siswa membuat refleksi dan kesimpulan atas materi yang dipelajari. Pada langkah ini guru dan siswa harus aktif dalam proses belajar mengajar.

Hasil penelitian diatas senada dengan pendapat (Martinis Yamin \& Bansu 2008:90) yaitu guru membagi teks berupa bacaan lembar kerja kepada siswa, siswa membaca teks dan membuat rangkuman, siswa berkolaborasi dan berinteraksi dengan teman satu kelompok, siswa mengkontruksi pengetahuannya secara individu dan guru dan siswa membuat refleksi dan kesimpulan. Berdasarkan hasil penelitian dan teori yang dikaji maka dapat dimaknai bahwa penerapan metode pembelajaran pembelajaran Think-Talk-Write (TTW) melalui lima langkah.

Peningkatan hasil belajar siswa pada mata pelajaran Pendidikan Kewarganegaraan pada siswa kelas X Sekolah Menengah Atas Negeri 1 Banyuke Hulu Kabupaten Landak.

Berdasarkan analisa data keseluruhan dari pra tindakan, siklus I, dan siklus II diatas bahwa terdapat peningkatan hasil belajar siswa dengan mengunakan metode pembelajaran Think-Talk-Write (TTW) pada mata pelajaran pendidikan kewarganegaraan kelas X Sekolah Menengah Atas Negeri 1 Banyuke Hulu Kabupaten Landak. Hal ini dapat dilihat dari tes kemampuan hasil belajar pra tindakan siswa berjumlah 29 orang memperoleh nilai tuntas sebanyak 9 orang siswa dengan presentase ketuntasan klasikal yaitu sebesar 31\%. Setelah dilakukan siklus I siswa yang memperoleh nilai tuntas 
sebanyak 18 orang siswa dengan presentase ketuntasan klasikal yaitu sebesar $62 \%$ dari 29 orang siswa yang mengikuti tes. Selanjutnya setelah dilakukan siklus II siswa yang memperoleh nilai tuntas sebanyak 25 orang siswa dengan presentase ketuntasan klasikal yaitu $86 \%$ dari 29 orang siswa yang mengikuti tes. Hal ini sejalan dengan hasil penelitian yang dilakukan oleh Rohani dan Samsiar (2017:58), menyatakan bahwa terdapat peningkatan civic knowledge siswa melalui penerapan model pembelajaran controversial issues pada mata pelajaran pendidikan kewarganegaraan dikelas VIII Sekolah Menegah Pertama Mujahidin Pontianak. Bisa dilihat dari perolehan tes hasil belajar siswa dimulai dari pra siklus mendapat ketuntasan klasikal 37,8\% dengan nilai rata-rata 69, ditunjukan dengan siklus I mengalami peningkatan dengan ketuntasan klasikal 56,75\% dengan nilai rata-rata 71,35 dan siklus II mengalami peningkatan dengan ketuntasan klasikal 77,14\% dengan nilai rata-rata 80. Selanjutnya penelitian lain Rohani (2017) menyatakan bahwa Terdapat peningkatan kemampuan kogntitif mahasiswa dengan menggunakan model course review horay pada mata kuliah pengantar pendidikan semester I Program Studi PPKn. Kemampuan kognitif mahasiswa pra siklus yang berjumlah 33 orang memperoleh nilai tuntas sebanyak 11 orang mahasiswa yaitu 33\% dengan persentase ketuntasan secara klasikal yaitu 25,82\%. Setelah dilakukan siklus I mahasiswa yang memperoleh nilai tuntas sebanyak 16 orang mahasiswa yaitu $48 \%$ dengan persentase ketuntasan klasikal sebesar 40,91\% dari 33 orang mahasiswa yang mengikuti tes. Selanjutnya setelah dilakukan siklus II mahasiswa yang memperoleh nilai tuntas sebanyak 29 orang mahasiswa yaitu $88 \%$ dengan persentase ketuntasan klasikal sebesar 70,85\% dari 33 orang mahasiswa yang mengikuti tes. Dari beberapa penelitian di atas dapat disimpulkan bahwa penerapan model pembelajaran dapat meningkatkan hasil belajar.

Berdasarkan tabel dibawah ini menampilkan data mengenai perkembangan hasil belajar siswa dari penelitian tindakan kelas yang telah dilakukan dari pra tindakan, siklus I dan siklus II yaitu sebagai berikut :

\section{Tabel 1}

\section{Peningkatan Hasil Belajar Siswa}

\begin{tabular}{cccc}
\hline Keterangan & Pra Tindakan & Siklus I & Siklus II \\
\hline Tuntas & 9 & 18 & 25 \\
\hline Belum tuntas & 20 & 11 & 4 \\
\hline Nilai tertinggi & 75 & 85 & 90 \\
\hline Nilai terendah & 45 & 55 & 65 \\
\hline Rata-rata & 62,65 & 71,93 & 77,10
\end{tabular}




\begin{tabular}{cccc}
\hline Jumlah & 1795 & 2070 & 2260 \\
\hline Ketuntasan klasikal & $31 \%$ & $62 \%$ & $86 \%$ \\
\hline
\end{tabular}

Sumber: Hasil Penelitian 2018

Evaluasi hasil belajar dilakukan sehari setelah pelaksanaan siklus I dan II adapun evaluasi hasil belajar siklus I terdapat 18 orang siswa yang tuntas dan yang belum tuntas 11 orang siswa, nilai tertinggi 85 dan nilai terendah 55 dengan nilai rata-rata mencapai 71,93 dan ketuntasan klasikal mencapai $62 \%$. Selanjutnya evaluasi hasil belajar siklus II terdapat 25 orang siswa yang tuntas dan yang belum tuntas 4 orang siswa, nilai tertinggi 90 dan nilai terendah 65 , dengan nilai rata-rata 77,10 dan ketuntasan klasikal mencapai $86 \%$.

Penelitian tindakan kelas ini dapat dikatakan berhasil, melihat dari gambar dibawah ini terjadi peningkatan hasil belajar baik dari nilai rata-rata kelas, ketuntasan klasikal maupun berdasarkan peningkatan jumlah siswa yang tuntas.

\section{Grafik 1}

\section{Presentase Ketuntasan Hasil Belajar Siswa Pra Tindakan, Siklus I dan Siklus II}

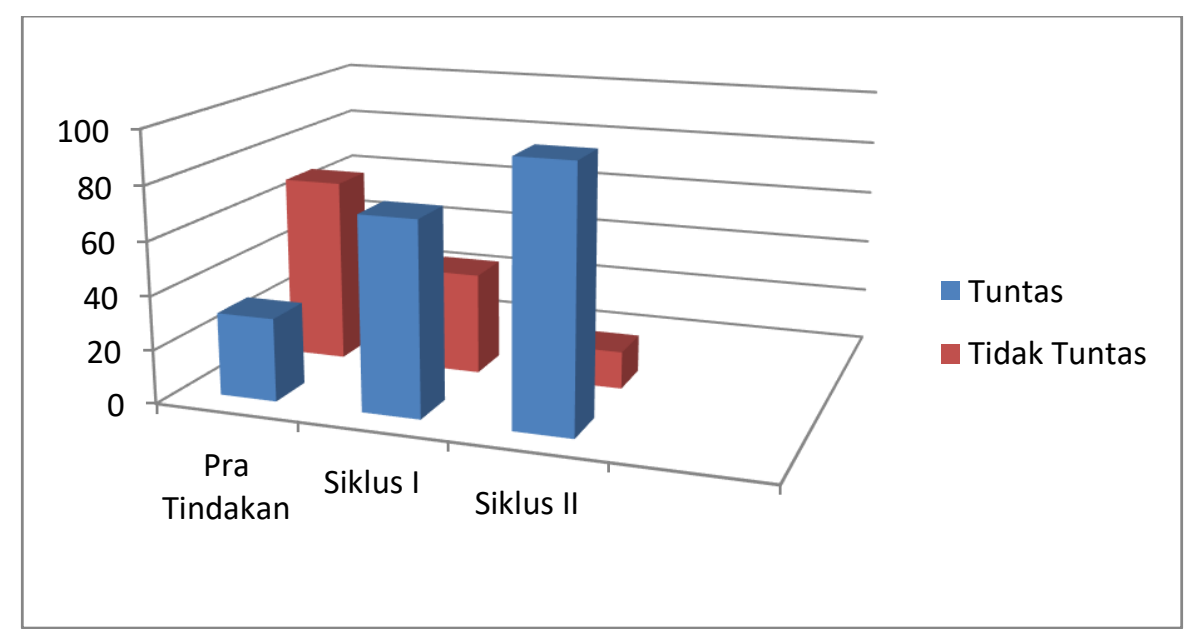


Penelitian tindakan kelas ini dapat dikatakan berhasil, melihat dari gambar presentase grafik diatas terjadi peningkatan hasil belajar baik dari nilai rata-rata kelas, ketuntasan klasikal, maupun berdasarkan peningkatan jumlah siswa yang tuntas. Hasil tersebut menunjukkan bahwa terjadi peningkatan nlai rata-rata dan ketuntasan klasikal hasil belajar secara bertahap dari pra tindakan, siklus I dan siklus II, dengan demikian maka peningkatan belajar dengan mengunakan metode pembelajaran Think-Talk-Write (TTW) kelas X Sekolah Menegah Atas Negeri 1 Banyuke Hulu Kabupaten Landak berhasil.

\section{SIMPULAN}

Berdasarkan hasil penelitian diperoleh kesimpulan bahwa penerapan metode pembelajaran Think-Talk-Write di Kelas X Sekolah Menengah Atas Negeri 1 Banyuke Hulu Kabupaten Landak tergolong baik, karena proses pembelajaran berjalan sesuai dengan rencana pelaksanaan pembelajaran (RPP), materi yang disajikan guru menarik perhatian siswa, siswa aktiv dalam belajar yang mengakibatkan meningkatnya hasil belajar. Terdapat peningkatan hasil belajar setiap sikluasnya melalui penerapan metode pembelajaran Think-Talk-Write. Hasil belajar siklus I terdapat 18 orang siswa yang tuntas dan yang belum tuntas 11 orang siswa, nilai tertinggi 85 dan nilai terendah 55 dengan nilai rata-rata mencapai 71,93 dan ketuntasan klasikal mencapai 62\%. Selanjutnya evaluasi hasil belajar siklus II terdapat 25 orang siswa yang tuntas dan yang belum tuntas 4 orang siswa, nilai tertinggi 90 dan nilai terendah 65, dengan nilai rata-rata 77,10 dan ketuntasan klasikal mencapai 86\% dengan kategori tinggi.

\section{DAFTAR PUSTAKA}

Arikunto, S.,dkk, 2014, Penelitian Tindakan Kelas. Jakarta: Bumi Aksara.

Burn, A. 2010, Doing Action Research In English Language Teaching A Guide For Pratitioners. Australia: Departemen Of Linguistich, Macquarie University.

Darmadi, H 2013. Pendidikan Pancasila dan Kewarganegaraan, Bandung: Alfabeta 2014. Pengantar Pendidikan Kewarganegaraan. Bandung:Alfabeta

Gregory, S. C. H. 2013. The Importance Of Action Reseach In Teacher Education Program, Journal Issues In Educational Research. Volume 23 Number 2.p.

Rohani. 2017. Peningkatan Kemampuan Kognitif Mahasiswa Melalui Penerapan Model Course Review Horay Pada Mata Kuliah Pengantar Pendidikan. Jurnal Pendidikan Kewarganegaraan, Vol. 1, No. 1 Juni 2017, Hal 78-86.

Rohani dan Samsiar. 2017. Upaya Guru dalam Meningkatkan Civic Knowledge Siswa melalui Model Pembelajaran Controversial Issues pada Mata Pelajaran Pendidikan Kewarganegaraan di

Kelas VIII Sekolah Menengah Pertama Mujahidin Pontianak. Jurnal Pendidikan Kewarganegaraan. Vol. 7. No. 1. Hal 49-59.

Undang-Undang No. 20 Tahun 2002 Tentang Sistem Pendidikan Nasional. 
Yamin, M dan Ansari B.I. 20108. Taktik Mengembangkan Kemampuan Individual Siswa. Jakarta. Gaung Persada Press. 